\title{
A KISKERESKEDELEM TERÜLETI JELLEGZETESSÉGEI A SZLOVÁK-MAGYAR HATÁRTÉRSÉGBEN
}

\author{
(The Charactheristics of Retail Trade in the Hungarian- \\ Slovakian Border Region)
}

KOVÁCS ANDRÁS

\begin{abstract}
Kulcsszavak:
kiskereskedelmi üzlethálózat vásárlási szokások vásárlási költés kiskereskedelmi vonzáskörzet vásárlási gyakoriság

A szlovák-magyar határ menti térségben élók a múltban és napjainkban egyaránt rendszeresen keresték, keresik fel a határ túloldalán müködö kereskedelmi létesitményeket. Ez a jelenség évtizedes múltra tekint vissza a határrégióban, azonban napjainkban, az uniós és schengeni csatlakozás után egyre nagyobb jelentöségüvé válik, mert a határon túli vásárlásokat már nem kolátozza a szigori határellenörzés vagy vámfizetési kötelezettség.

Tanulmányunkban feltérképezzük a határtérség két oldalának kereskedelmi hálózatát, majd áttekintjük azokat a rövid és hosszú távon ható gazdasági folyamatokat és térszerkezeti jellemzöket, amelyek befolyásolják a határon átnyúló bevásárlóturizmus volumenét és irányát. A térségben végzett empirikus kutatások eredményeinek bemutatásával megkisérlïnk választ adni arra, hogy a határ menti bevásárlóturizmus milyen volumenü, mekkora térségre terjed ki (vonzáskörzetek), és a határ túloldalán vásárlók milyen rendszerességgel mekkora összegeket költenek.
\end{abstract}

\section{Kiskereskedelem és hatảrmentiség}

A kiskereskedelmi üzletek elsődleges feladata, hogy egy településen, illetve annak vonzáskörzetében élöknek biztosítják az áruk és szolgáltatások megfelelỏ színvonalú ellátását. A határ menti térségekben múködő kereskedelmi egységek azonban a fenti alapvető funkción túl a határon túl élók ellátási színvonalát is javíthatják (bevásárlóturizmus), valamint profitot realizálhatnak a határátkelóhelyek tranzitforgalmából (pl. üzemanyag-vásárlás stb.).

A határ menti térségekben tapasztalható bevásárlóturizmus intenzitása számos tényezó függvénye. Ezek alapvetően befolyásolják a vásárlási mozgások irányát, gyakoriságát, a határon túl elköltött összegek nagyságát, a fogyasztói kosarak öszszetételét stb. A legfontosabb befolyásoló tényezők:

- Természetföldrajzi meghatározottságok és infrastrukturális kapcsolatok (domborzat, vízhálózat, útviszonyok);

- A településhálózat térkapcsolatainak jellege (regionális központok elhelyezkedése, határon átnyúló vonzáskörzetek);

- A két ország valutájának egymáshoz viszonyított árszínvonala, ill. ennek változása, ingadozása; 
- A határ két oldalán elérhető termékek és szolgáltatások jellege és minősége közti különbség (elérhető márkák, speciális termékek);

- A termékeket és szolgáltatásokat terhelő adószintek közti különbségek (ÁFAszint, jövedéki adók mértéke stb.).

A szlovák-magyar határtérségben a határon túli vásárlások intenzitása, és ennek a kiskereskedelmi hálózat alakulására kifejtett hatása az elmúlt évtizedekben változó volt, azonban még a szocializmus évtizedei alatt sem szünt meg teljesen ${ }^{1}$. Az 1920 elött évszázadokig funkcionálisan és közigazgatásilag egyaránt összetartozó térségek természetes kapcsolatrendszerét az új államhatár és az évtizedekig tartó szigorúan szabályozott (és korlátozott) személy, áru, tőke és szolgáltatás-áramlás sem tudta eltörölni. Mivel a településhálózat „lassú reagálású rendszer”, a korábban meglévő gazdasági-társadalmi, településhálózati kapcsolatok napjaink egységes európai piacán újjászövődnek.

Az uniós csatlakozással járó 4 szabadság ${ }^{3}$ eredményeként a magyar-szlovák határtérségben megindult jelentős számú munkavállaló, vállalkozó, a térségben élő család és ide látogató turista rendszeres, határon átnyúló mozgása. Ennek jelentős hatása van a határtérségben vásárlók mozgására, költéseire, ezáltal a kiskereskedelmi hálózat további fejlődésére.

A tanulmány további részében a magyar-szlovák határtérség kereskedelmi hálózatát, az itt élők vásárlási szokásait elemezzük. Az értékelés során hangsúlyt fektetünk annak bemutatására, hogyan befolyásolják a határ menti kiskereskedelmi mozgásokat, ,átvonzásokat” a térség térszerkezeti, infrastrukturális kapcsolatrendszerei, és az olyan rövid távon érvényesülö hatások, mint az árszínvonal vagy az adóterhek közötti különbség.

\section{Kiskereskedelem Magyarországon és Szlovákiában}

A rendszerváltás után Magyarországon és Szlovákiában egyaránt nagy gyorsasággal megindult a kiskereskedelmi hálózat átalakulása. Az átalakulási folyamat kulcselemei a következök voltak:

- A korábban állami tulajdonban lévő vállalatokat privatizálták.

- Nagyszámú hazai kisvállalkozó kezdte meg múködését a kiskereskedelemben, a korábbi keresletvezérelt piac kinálatvezérelt piaccá alakult a kielncvenes évek elején

- Mindkét ország piacán megjelentek, elterjedtek, napjainkra pedig dominánssá váltak a külföldi tulajdonban lévő kiskereskedelmi hálózatok (1. táblázat).

Fenti folyamatok eredményeként napjainkra teljesen átalakultak a vásárlási szokások, az üzletekbe látogatók az élményorientált vásárlást helyezik elótérbe, és az olyan kiskereskedelmi létesítményeket preferálják, ahol nagyszámú termék és szolgáltatás érhető el egy helyen (bevásárlóközpontok, hipermarketek). 
Kovács András : A kiskereskedelem területi jellegzetességei a szlovák-magyar határtérségben.

Tér és Társadalom 22. évf. 2008/3. 97-107. p.

TÉT XXII. évf. 2008 - 3

A kiskereskedelem területi ...

99

TOP 10 élelmiszerkereskedö Magyarországon és Szlovákiában, 2007 (TOP 10 Food Mart Chains in Hungary and in Slovakia)

\begin{tabular}{|c|c|c|c|c|c|}
\hline \multicolumn{3}{|c|}{ Magyarország } & \multicolumn{3}{|c|}{ Szlovákia } \\
\hline Sorszám & Cég & $\begin{array}{c}\text { Forgalom, } \\
\text { MHUF }\end{array}$ & Sorszám & Cég & $\begin{array}{c}\text { Forgalom, } \\
\text { MHUF* }\end{array}$ \\
\hline 1. & Tesco & 554,9 & 1. & Tesco Stores & 185,2 \\
\hline 2. & CBA & 525,0 & 2. & Metro SR & 112,4 \\
\hline 3. & Coop & 440,0 & 3. & Billa & 84,9 \\
\hline 4. & Reál & 331,0 & 4. & Kaufland & 77,6 \\
\hline 5. & Spar & 284,5 & 5. & Ahold Retail SR & 44,7 \\
\hline 6. & Metro & 232,0 & 6. & CBA Slovakia & 41,0 \\
\hline 7. & Auchan & 212,0 & 7. & Lidl & 37,2 \\
\hline 8. & Penny Market & 145,1 & 8. & Labaš & 26,2 \\
\hline 9. & Lidl & 124,1 & 9. & $\begin{array}{l}\text { COOP Jednota } \\
\text { Bratislava }\end{array}$ & 21,7 \\
\hline 10. & Cora & 118,8 & 10. & $\begin{array}{l}\text { COOP Jednota } \\
\text { Nové Zámky }\end{array}$ & 20,1 \\
\hline
\end{tabular}

*7,98 HUF/SKK árfolyamon (2008. ápr. 1.).

Forrás: AC Nielsen, www. tvojepeniaze.pravda.sk.

A kereskedelmi hálózat átalakulása és az új típusú, nagy alapterületú kiskereskedelmi létesítmények fejlődése Magyarországon már 1996-ban megkezdődött, ekkor nyílt meg Budapesten az első kettő, 3. generációs bevásárlóközpont, a Duna Plaza és a Pólus Center, valamint az első Tesco hipermarket (Sikos T. 2000). Szlovákiában ez a folyamat csak a kilencvenes évek végén kezdődött meg, az első Tesco hipermarket 1999-ben, az első pozsonyi bevásárlóközpont, a Danubia, 2000 júniusában nyílt meg (Sikos T. 2007).

2008-ra a külföldi tulajdonban lévő kiskereskedelmi hálózatok dominálják mind a magyarországi, mind a szovákiai kiskereskedelmet. Amíg Magyarországon a hazai tulajdonban lévő CBA, a Coop szövetkezeti hálózat és a beszerzési társulásként müködő Reál előkelő helyet foglal el a kiskereskedők versenyében, addig Szlovákiában a hazai kiskereskedők, a Labas, a pozsonyi és érsekújvári Coop Jednota a TOP 10-es lista utolsó három helyére szorultak (1. táblázat).

\section{A magyar-szlovák határtérség kiskereskedelmi hálózata}

A kiskereskedelmi egységek telephelyválasztását alapvetően a potenciális telephely (város), ill. vonzáskörzetének lakónépességszáma és az ott élök jövedelmi színvonala határozza meg. A térség kiskereskedelmi hálózatának fejlettsége jól jellemezhető a bevásárlóközpontok, a hipermarketek és szupermarketek elterjedtségével. 
Kovács András : A kiskereskedelem területi jellegzetességei a szlovák-magyar határtérségben.

Tér és Társadalom 22. évf. 2008/3. 97-107. p.

A bevásárlóközpontok jövedelemző müködéséhez minimum 100 ezer potenciális vásárló szükséges a központ vonzáskörzetében (Sikos T.-Hoffmann 2004) . A határtérség mindkét oldalán csak néhány jelentös település (Györ, Miskolc, Tatabánya, Pozsony, Kassa, Érsekújvár, Észak- és Dél-Komárom együtt) képes ekkora vásárlóerőt biztosítani. Ezek a határ közeli bevásárlóközpontok (Győr Árkád, Győr Plaza, Miskolc Plaza stb.) kiemelt szerepet játszanak a határon átnyúló kereskedelmi folyamatok formálódásában. Ennek elemzésére a következő felyezetben visszatérünk.

A magyar-szlovák határtérség mindkét oldalán a nagyterületü élelmiszerkereskedelmi egységek piacán a Tesco a piacvezető. Az angol kiskereskedelmi lánc magyarországi versenytársa az Interspar, míg Szlovákiában a Hypernova és a Kaufland hipermarketek. Ezek az egységek a minimum 20-30 ezer fös lakónépességgel rendelkező városokban telepedtek le. A fontosabb szupermarket- és diszkontláncok térbeli eloszlása sokkal egyenletesebb, ezek az elsősorban élelmiszereket értékesítő egységek már 10 ezer fơs lakónépességgel bíró településen is jól tudnak prosperálni (2. és 3. táblázat).

\section{TÁBLÁZAT}

Jelentös élelmiszerkereskedelmi hálózatok a magyar-szlovák határtérség magyarországi oldalán, 2008

(Important Retailers on the Hungarian Side of the Hungarian-Slovakian Border Region, 2008)

\begin{tabular}{|c|c|c|c|c|c|c|c|}
\hline Település & Tesco & Interspar & Spar & Profi & Lidl & $\begin{array}{c}\text { Penny } \\
\text { Market }\end{array}$ & $\begin{array}{l}\text { Coop } \\
s m\end{array}$ \\
\hline Csorna & 1 & & 1 & & 1 & 1 & \\
\hline Mosonmagyaróvár & 1 & & & & 1 & 1 & \\
\hline Győr & 1 & 2 & & & & & \\
\hline Komárom & 1 & & 2 & & & 1 & \\
\hline Tata & 1 & & 2 & 1 & & 1 & \\
\hline Tatabánya & 1 & 1 & 7 & 1 & 1 & 2 & \\
\hline Dorog & & & 1 & 1 & & 1 & \\
\hline Esztergom & 1 & & & & & & \\
\hline Pilisvörösvár & & & 1 & & & & \\
\hline Szentendre & & 1 & & & 1 & & \\
\hline Vác & & & & 1 & 1 & & \\
\hline Balassagyarmat & & & 1 & & 1 & 1 & 1 \\
\hline Salgótarján & 1 & & 2 & 1 & & 1 & \\
\hline Pásztó & & & & & & 1 & \\
\hline Bátonyterenye & & & & & & 1 & \\
\hline Edelény & & & & 1 & & 1 & \\
\hline Kazincbarcika & 1 & & 1 & 1 & 1 & 1 & \\
\hline Miskolc & 1 & 1 & 1 & 1 & 3 & 3 & 1 \\
\hline Ózd & 1 & 1 & & 1 & & 1 & 1 \\
\hline Sárospatak & & & & 1 & & & \\
\hline Sátoraljaújhely & 1 & & & & & 1 & \\
\hline
\end{tabular}


Kovács András : A kiskereskedelem területi jellegzetességei a szlovák-magyar határtérségben.

Tér és Társadalom 22. évf. 2008/3. 97-107. p.

TÉT XXII. évf. 2008 घ 3

A kiskereskedelem területi ... 101

\section{TÁBLÁZAT}

Jelentős élelmiszerkereskedelmi hálózatok a magyar-szlovák határtérség szlovákiai oldalán, 2008

(Important Retailers on the Slovakian Side of the Hungarian-Slovakian

Border Region, 2008)

\begin{tabular}{|c|c|c|c|c|c|c|c|}
\hline Település & Tesco & Hypernova & Kaufland & Terno & Lidl & Billa & $\begin{array}{l}\text { Coop } \\
\operatorname{sm}^{*}\end{array}$ \\
\hline Pozsony & 5 & 1 & 2 & 3 & 5 & 13 & 14 \\
\hline Somorja & & & & & 1 & 1 & 1 \\
\hline Dunaszerdahely & & 1 & 1 & & 1 & & 4 \\
\hline Nagymegyer & & & & & & 1 & 1 \\
\hline Komárom & & 1 & 1 & & & 1 & 3 \\
\hline Ógyalla & & & & & 1 & & 1 \\
\hline Gúta & 1 & & & & & & 1 \\
\hline Érsekújvár & 1 & 1 & 1 & 1 & 1 & 1 & 2 \\
\hline Párkány & & & & 1 & 1 & 1 & \\
\hline Ipolyság & & & & & 1 & 1 & 1 \\
\hline Zselíz & & & & & 1 & & 1 \\
\hline Léva & 1 & 1 & 1 & 1 & & 3 & 1 \\
\hline Losonc & 1 & 1 & & & 1 & 2 & \\
\hline Fülek & & & & & & 1 & \\
\hline Rimaszombat & & 1 & 1 & & 1 & 1 & \\
\hline Nagykürtös & & & & & 1 & 1 & \\
\hline Tornalja & 1 & & & & & & \\
\hline Rozsnyó & 1 & & & & 1 & 1 & \\
\hline Szepsi & 1 & & & & & 1 & \\
\hline Kassa & 3 & 1 & 2 & & 4 & 3 & 1 \\
\hline \multicolumn{8}{|l|}{ Gálszécs } \\
\hline Töketerebes & & & & 1 & 1 & 1 & \\
\hline Királyhelmec & 1 & & & & & & 2 \\
\hline Nagykapos & 1 & & & & 1 & & 1 \\
\hline
\end{tabular}

* sm= szupermarket.

Forrás: A cégek internetes üzletlistája alapján saját szerkesztés.

\section{Vásárlási szokások a határ mentén}

A magyar-szlovák határ menti térség kereskedelmi szerkezetének bemutatása után a következökben az itt élők vásárlási szokásait elemezzük, különös tekintettel a határ túloldalán bonyolított vásárlásaikra.

A vásárlási szokások értékelése elött áttekintjük azokat a rövid, közép, ill. hosszú távon ható gazdasági folyamatokat és térszerkezeti jellemzőket, amelyek a határ menti térségben zajló kiskereskedelmi áramlásokat befolyásolják. 
Kovács András : A kiskereskedelem területi jellegzetességei a szlovák-magyar határtérségben. Tér és Társadalom 22. évf. 2008/3. 97-107. p.

A magyar és szlovák oldalon élők határon túli vásárlásait alapvetően befolyásolja, hogy hogyan alakul a két ország valutájának egymáshoz viszonyított árfolyama. A korona forinthoz viszonyitott árfolyama az utóbbi 10 évben egy hosszú stabil árfolyamszint után az utóbbi 5 évben folyamatosan nőtt (1. ábra). Az elsősorban Szlovákia gyors gazdasági növekedését és az ERM II. árfolyamrendszerbe ${ }^{4}$ való belépését követő árfolyamnövekedés 2005 és 2008 között a szlovák fizetöeszköz egy egységét közel 30\%-kal drágította meg a forinthoz viszonyítva. Ez az árfolyamszint változás a magyarországi oldalon élőknek megdrágította, a szlovákiai oldalon élőknek olcsóbbá tette a határon túli bevásárlásokat.

\section{1. ÁBRA}

A forint és korona devizaárfolyamának alakulása, 1997-2008

(Exchange Rate of HUF and SKK, 1997-2008)

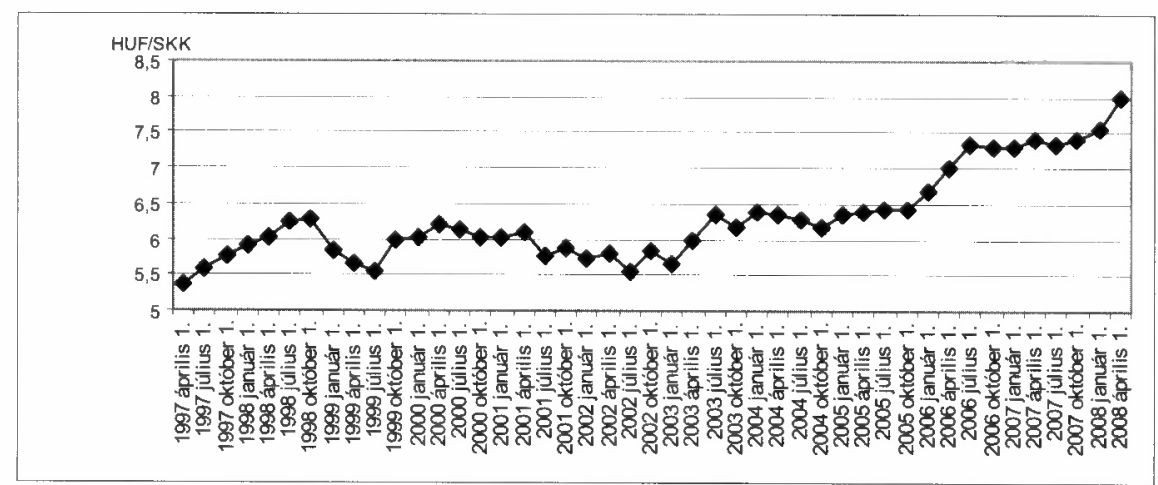

Forrás: MNB, www.mnb.hu

Azonban nemcsak az árfolyamok változása képes befolyásolni viszonylag gyorsan a határ menti kereskedelemmel kapcsolatos mozgásokat, hanem olyan egyszeri adminisztratív szabályozók megváltozása is, mint az adótörvények, adó- és járulékszintek. Ennek legjobb példája az évtizedes szlovák-magyar üzemanyagturizmus megszünése. A kilencvenes években a szlovák üzemanyagokat terhelő adók alacsonyabb szintje miatt a határ menti térségben élök rendszeresen jártak át a határ túloldalára üzemanyagot vásárolni. Az üzemanyagok adójának szlovákiai emelése (és a korona árfolyamának korábban bemutatott emelkedése) után a magyarországi és szlovákiai üzemanyag jerlentős árkülönbsége megszünt, és mára gyakorlatilag eltünt a határ menti kereskedelem e formája.

Jóllehet bizonyos termékek vagy termékcsoportok határ menti kereskedelmét alapvetően befolyásolja az árfolyamok vagy az adójogszabályok változása, a térség településszerkezetének kapcsolatrendszere, a regionális központok (Györ, Miskolc, Kassa) határon átnyúló vonzóhatása és a gazdasági kapcsolatok újjáalakulása hoszszú távon megalapozza a határ menti kereskedelem alakulását.

A Csallóközben élőknek Győr a legközelebbi nagyváros, ahol magasabb szintü szolgáltatásokat vehetnek igénybe (bevásárlóközpontok, színház, mozi stb.). A gyö- 
Kovács András : A kiskereskedelem területi jellegzetességei a szlovák-magyar határtérségben. Tér és Társadalom 22. évf. 2008/3. 97-107. p.

TÉT XXII. évf. 2008 — 3

A kiskereskedelem területi ...

103

ri, komáromi és esztergomi ipari parkokban több mint 20 ezer szlovákiai állampolgár (többségében felvidéki magyar) dolgozik, és jelentős részük forintban kapja fizetését. Ezek a térszekezeti és gazdasági kapcsolatok hosszú távon befolyásolják a határ menti kereskedelem fejlödését és jellegét (Kovács-Szabó 2008).

A továbbiakban a határ menti térségben végzett empirikus kutatásaink határ menti kereskedelmet érintő eredményeit mutatjuk be és elemezzük.

Kutatásunk során (1000 [HU] - 996 [SK] fős lakossági megkérdezés) a magyarországi megkérdezettek 13\%-a, a szlovákiai oldalon élők 27\%-a nyilatkozta azt, hogy legalább havi rendszerességel utazik a határ túloldalára, míg a magyarországiak $21 \%$-a és a szlovákiaiak mindössze $5 \%$-a állította, hogy sosem lépi át a határt.

A határ átlépésének leggyakoribb oka az üdüléshez és pihenéshez, városnézéshez kapcsolódik mindkét oldalon (a megkérdezettek mintegy 30-35\%-a), azonban a válaszadók nem jelentéktelen része nyilatkozott úgy, hogy a határ túloldalán is szokott tartós fogyasztási cikkeket vásárolni, vagy a heti, havi nagybevásárlását lebonyolítani (2. ábra). A szlovákiai válaszadók közel 20\%-a (190fö) tartós fogyasztási cikkek vásárlása, $8 \%$-uk ( 83 fö) pedig a heti, havi nagybevásárlás miatt lépi át leggyakrabban a határt. Ez az arány a magyarországi válaszadóknál mindkét kategória esetében kevéssel 10\% felett van (122 és 131 fö). Jóllehet a megkérdezettek közül kevesen nyilatkoztak úgy, hogy a határátlépésük elsődleges indoka a bevásárlás, mégis fenti arányokat a határtérség teljes népességére vetítve azt kapjuk, hogy a határon túlról érkező vásárlók jelentős (több 10 ezer fős) többlet vásárlóerőt generálnak a határtérség városaiban.

Ennek a potenciális vásárlóerőnek a nagysága attól függ, hogy a határon túlról érkezők vásárlási gyakorisága és vásárlásonkénti költése mekkora.

2. ÁBRA

A határ átlépésének leggyakoribb oka

(The Most Frequent Purpose of Crossing the Border)

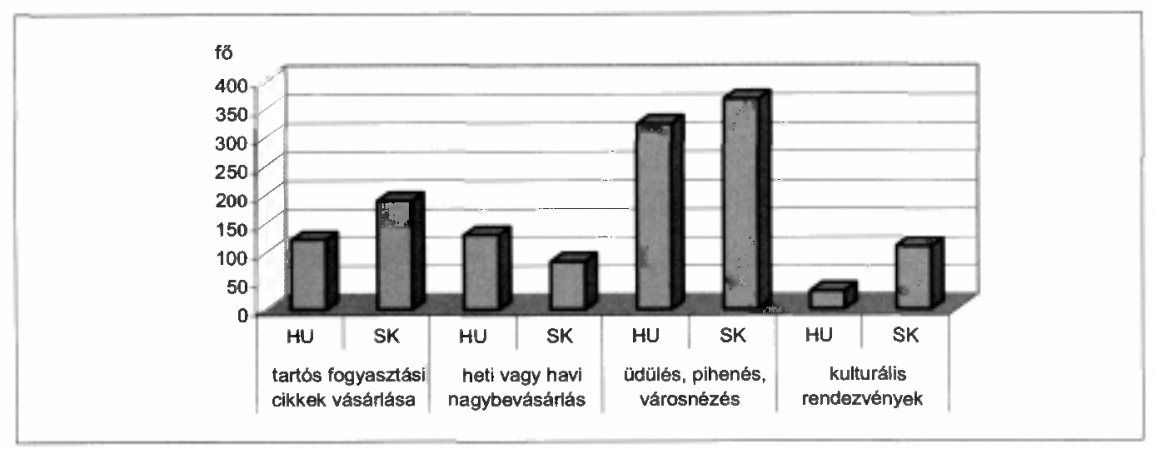

Forrás: Lakossági Kérdőív (2008). 
Kovács András : A kiskereskedelem területi jellegzetességei a szlovák-magyar határtérségben.

Tér és Társadalom 22. évf. 2008/3. 97-107. p.

A tartós fogyasztási cikkek, a heti vagy havi nagybevásárlás, üdülés vagy kulturális rendezvények látogatásánál egyaránt azt állapíthatjuk meg, hogy a határrégió szlovákiai oldalán élők gyakrabban veszik igénybe a határon túl (Magyarországon) ezeket a szolgáltatásokat, mint a magyarországiak Szlovákiában (3. ábra). A vásárlási gyakoriságokban tapasztalható különbség a heti vagy havi nagybevásárlások kivételével nem jelentős. Az azonban szembetủnő, hogy a magyarországi megkérdezettek több mint 80\%-a maximum évente néhányszor vásárol Szlovákiában, míg a szlovákiai oldalon élők 60\%-a legalább havi gyakorisággal vásárol Magyarországon.

\section{3. ÁBRA}

A határ átlépésének célja és gyakorisága

(The Aim and Frequency of Crossing the Border)

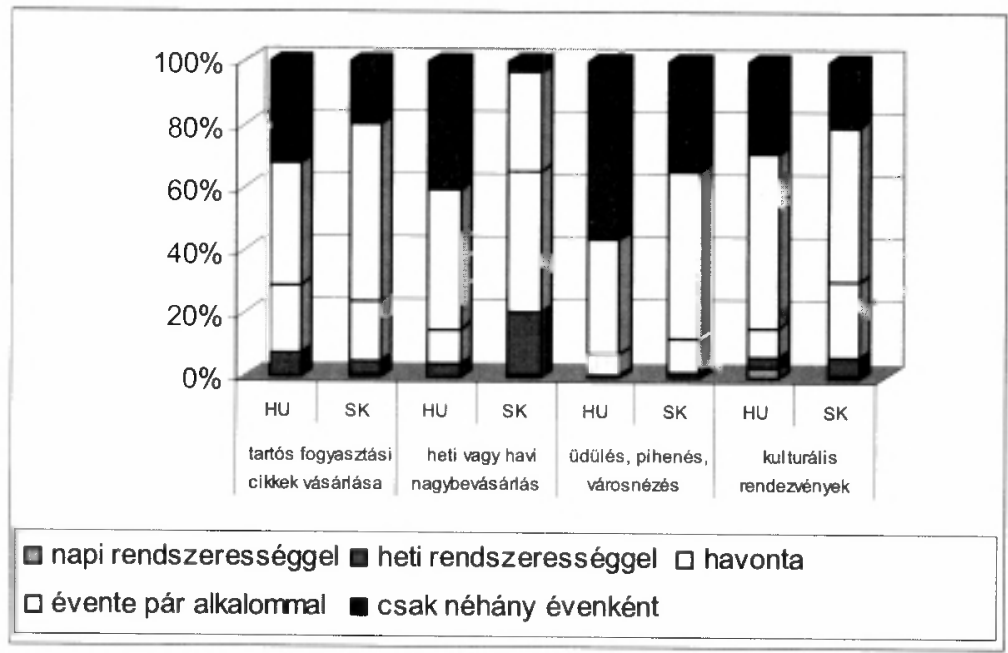

Forrás: Lakossági Kérdőív (2008).

A vásárlási gyakoriságokat elemezve megállapíthatjuk, hogy a magyarországi kereskedôk potenciálisan sokkal nagyobb számú vásárlóra számíthatnak, nagyobb forgalmat realizálhatnak a határon túlról érkező vásárlókkal.

A tartós fogyasztási cikkek vásárlása során a határon átkelö vásárlók töbsége (az összes megkérdezett 12\%-a Magyarországon és 19\%-a Szlovákiában) legalább évente néhányszor átkel a határon, hogy ilyen termékeket vásároljon. Mivel ezek sok esetben jelentős értéket képviselö áruk, a térség kiskereskedőinek jelentős többletbevételt eredményezhetnek a határon túlról érkező vásárlók.

A vásárlási gyakoriság mellett az egy vásárlásra jutó költések befolyásolják a határon túli vásárlások volumenét. A vásárlási költések megoszlása hasonló a határ mindkét oldalán, vagyis a magyarországi és szlovákiai bevásárlóturisták közel azonos arányban költenek vásárlásaik során. A határon túlról érkező vásárlók vásárlóere jelentős, hiszen többségük egy vásárlás során $20000 \mathrm{Ft}$-ot, vagy annál nagyobb összeget is elkölthet (4. ábra). Ennek oka feltételezhetően az, hogy a vásárlóknak csak ak- 
Kovács András : A kiskereskedelem területi jellegzetességei a szlovák-magyar határtérségben.

Tér és Társadalom 22. évf. 2008/3. 97-107. p.

kor érdemes a határ túloldalára utazni, ha egy alkalommal több, kedvezỏ áru terméket is meg tudnak vásárolni, így kompenzálva nagyobb utazási költségeiket.

\section{4. ÁBRA}

A határon túl vásárlók vásárlási költéseinek megoszlása

(The Share of Spendings of Cross-Border Purchasers)

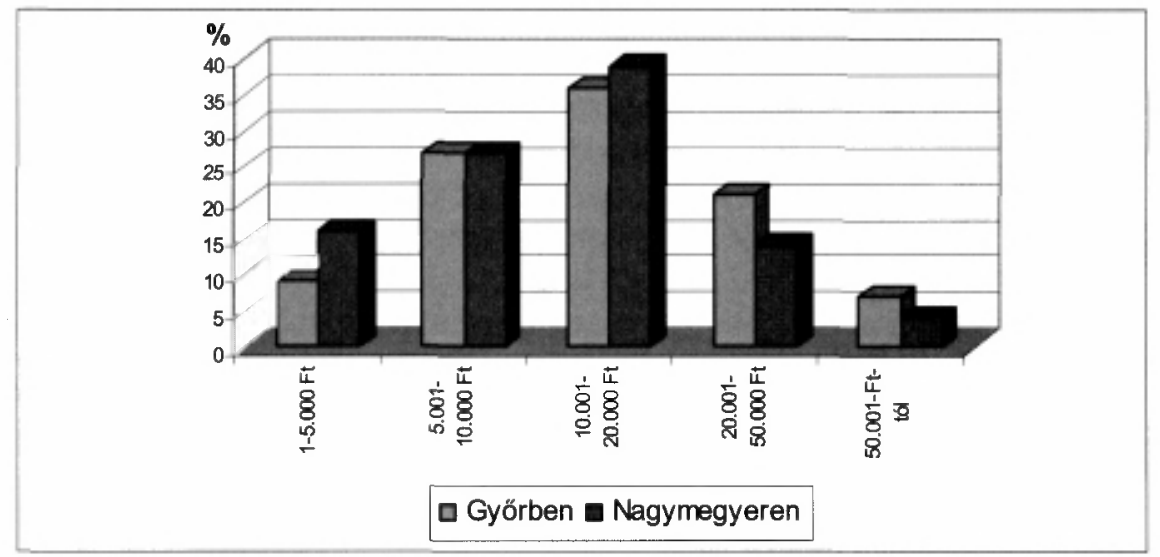

Forrás: Gazsó (2008) alapján saját szerkesztés.

A határ két oldalán mủködő kereskedelmi vállalkozások - a jelentős vásárlói mobilitás miatt - versenytársai is egymásnak (5. ábra). Az észak- és dél-komáromi hipermarketek (Hypernova, Kaufland, Tesco) versenyében a Tesco elönyre tett szert, mivel:

- Sikeres telephelyválasztásának köszönhetően nemesak a dél-komáromi vásárlók érik el könnyen, hanem az észak-komáromi lakosok jelentős részének is közelebb van lakhelyéhez, mint a két észak-komáromi hipermarket;

- A Tesco szélesebb termékkínálata vonzóbb, mint versenytársaié;

- A Tesco non-stop tart nyitva, szemben a két konkurrens 7-20 óráig tartó nyitvatartási idejével;

- A Tesco közlekedési szempontból kezdvező helyen épült fel, a vasútállomás és a buszvégállomás közvetlen közelében;

- Nagyszámú észak-komáromi forintban kapja fizetését, és annak egy részét Magyarországon (sok esetben a Tesco-ban) költi el. 
Kovács András : A kiskereskedelem területi jellegzetességei a szlovák-magyar határtérségben.

Tér és Társadalom 22. évf. 2008/3. 97-107. p.

\section{5. ÁBRA}

Az észak- és dél-komáromi hipermarketek vonzáskörzete (The Gravity Zone of Hypermarkets in Komárom and Komárno)

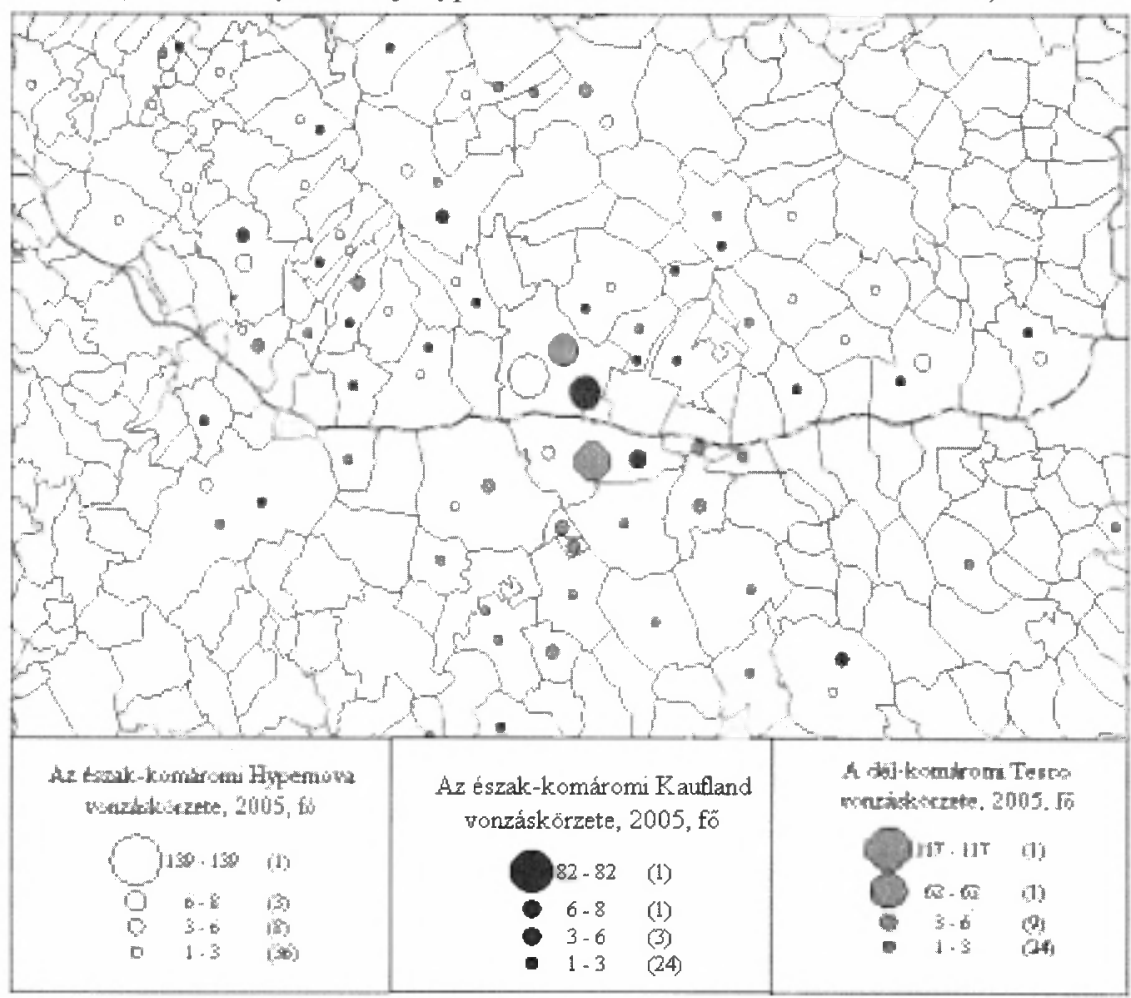

Forrás: Sikos T.-Tiner (2007).

\section{A határ menti kereskedelem jövője}

Kutatásunk során bebizonyosodott, hogy a határtérség kiskereskedelmi folyamatait, illetve a határon átnyúló kiskereskedelmi mozgásokat számos rövid és hosszú távon ható gazdasági adottság és térszerkezeti jellemző befolyásolja. A következókben bemutatjuk azokat a várható gazdasági folyamatokat, amelyek az elkövetkező években befolyásolni fogják a térségben élők határ túloldalára irányuló vásárlási szándékát:

- Az euró szlovákiai bevezetésének előkészítése során a korona árfolyamának további erősödése várható a forinthoz képest, így a szlovák valuta értéke túl magas lesz a magyar fizetöeszközben kifejezve, ezért egyre kevésbé lesz kifizetődő a magyarországi határtérségben élöknek Szlovákiában vásárolni.

- A korona (majd az euró) erősödése a forinthoz képest, valamint a napjainkban még magasabb színvonalú, szélesebb választékot kínáló magyarországi kereskedelmi hálózat (jelentős bevásárlóközpontok, nagyterületủ hipermarketek) potenciálisan több szlovákiai vásárlót vonzanak majd. 
Kovács András : A kiskereskedelem területi jellegzetességei a szlovák-magyar határtérségben.

Tér és Társadalom 22. évf. 2008/3. 97-107. p.

TÉT XXII. évf. 2008 — 3

A kiskereskedelem területi ...

107

- A közép- és hosszú távú vásárlóerő növekedés mindkét oldalon hozzájárulhat (kis mértékben) a határon túl történő vásárlások számának növekedéséhez.

- A kiskereskedelmi hálózat szlovákiai fejlődése (ủj bevásárlóközpontok és hipermarketek megnyitása) a határ menti térség városaiban (Dunaszerdahely MAX, Komárom - Aquario, Párkány - Aquario) azonban csökkentheti, helyenként minimumra redukálhatja a bevásárlás motiválta határátlépéseket.

\section{Jegyzetek}

${ }^{1}$ E sorok szerzőjének még élénken él emlékezetében, hogy a nyolcvanas években a Komárnoban megvásárolt cipöt csak lábon hordva lehetett áthozni a határon Magyarországra. Így a potenciális vásárlónak az odaúton a legkopottabb pár cipőjében kellett mennie, amitől a cipővásárlást kővetően még Szlová-

kiában meg kellett szabadulnia. Az új lábbeliket felvéve már szabad volt az út a határon...

2 Idézet Beluszky Páltól.

${ }^{3}$ Emberek, áruk, tơke, szolgáltatások szabad áramlása a Közösségen belül.

${ }^{4}$ ERM II. (Exhange Rate Mechanism II): Az Európai Monetáris Rendszer árfolyamrendszere. Minden eurozónához csatlakozni szándékozó országnak minimum 2 évig rögzített árfolyamsávban kell tartania nemzeti fizetőeszközének árfolyamát az euróhoz képest. Szlovákia várhatóan 2009. január elsején csatlakozik az euróövezethez, és lecseréli nemzeti valutáját az euróra.

\section{Irodalom}

Gazsó V. (2008) Bevásárlóturizmus a határ mentén Gyơr és Nagymegyer térségében. Selye János Egyetem, Komárno. Diplomadolgozat.

Kovács A.-Szabó I. (2008) Nemzetközi tökebefektetések munkaerőpiaci hatásai Komárom és Komámo térségében. - Földrajzi Értesitö. 3-4. (megjelenés alatt).

Sikos T. T. (2000) Marketingföldrajz. VÁTI, Budapest.

Sikos T. T. (2007) A kereskedelmi komplexumok terjedése Szlovákiában. - Sikos T. T. (szerk.) A bevásárlóközpontok jelene és jövöje. Selye János Egyetem Kutatóintézete, Komárno.

Sikos T. T.-Tiner T. (2007) Komárno - Komárom. Egy város két ország. Selye János Egyetem Kutatóintézete, Komámo.

Sikos T. T.-Hoffmann Istvánné (2004) A fogyasztás új katedrálisa. MTA-Társadalomkutató központ, Budapest.

\section{THE CHARACTHERISTICS OF RETAIL TRADE IN THE HUNGARIAN-SLOVAKIAN BORDER REGION}

\section{ANDRÁS KOVÁCS}

People living in the Hungarian-Slovakian border region have been shopping on the other side of the borderline for decades. This phenomena has got a long tradition in the area, but nowadays, after the EU and Schengen-accession it becomes more and more important, as there are no more strict border controls or high customs tariffs between Slovakia and Hungary.

The first part of the paper introduces the network of the retail-trade sector alongside the border, and analyses the short- and long-term economic trends and the spatial characteristics that are influencing the volume and direction of cross-border retail trade. On the basis of the results of our empirical researches I will attempt to determine the volume and spatial extent of the cross-border shopping tourism (gravity zones), and to give a short overview of the average spendings and shopping frequency of cross-border shoppers. 